\title{
Colorectal Nonadenocarcinoma in South Korea
}

\author{
Jung Wook Huh \\ Department of Surgery, Samsung Medical Center, Sungkyunkwan University School of Medicine, Seoul, Korea
}

\section{See Articles on Page 390-397}

Although most colorectal cancers are adenocarcinomas, there are several histological types of colorectal cancers, such as neuroendocrine tumors (NETs), lymphomas, gastrointestinal tumors (GISTs), melanomas, squamous cell carcinoma, and sarcomas, accounting for $2 \%-6 \%$ of all colorectal cancers $[1,2]$. Using a nationwide, population-based cancer registry, the authors investigated the incidence and clinical characteristics for these rare colorectal cancers [2]. This analysis was performed to update the incidences of rare histological types of colorectal cancers in South Korea. I believe that this analysis can facilitate further investigations regarding more accurate prognosis and clinical impact in the future.

NETs originate from the diffuse system of neuroendocrine cells and constitute $2 \%$ of all gastrointestinal (GI) malignancies [3]. Although colonic NETs are rare, their incidence has been increasing from 0.002 per 100,000 individuals in 1973 to 0.2 per 100,000 individuals in 2004, according to a western registry [4]. Approximately $70 \%$ of colonic NETs occur in the right colon, especially in the cecum [5]. Moreover, the incidence of rectal NETs has been increased 10 -fold over the last 30 years, which is approximately 1 per 100,000 individuals [6]. A previous Korean study showed that the mean age at diagnosis of rectal NETs was 50 years and rectal NETs were somewhat more common in males than in females [7]. Complete resection of NETs is generally recommended according to their size, but other treatment options are also available [3].

GISTs are the most common GI mesenchymal tumors and account for $0.1 \%-3.0 \%$ of all GI malignancies $[8,9]$. The annual incidence of GISTs is estimated to be 1-2 per 100,000 individuals

Correspondence to: Jung Wook Huh, M.D.

Department of Surgery, Samsung Medical Center, Sungkyunkwan University School of Medicine, 81 Irwon-ro, Gangnam-gu, Seoul 06351, Korea

Tel: +82-2-3410-1826, Fax: +82-2-3410-6980

E-mail: jungwook.huh@gmail.com

ORCID: https://orcid.org/0000-0002-4485-0184

(C) 2020 The Korean Society of Coloproctology

This is an open-access article distributed under the terms of the Creative Commons Attribution NonCommercial License (https://creativecommons.org/licenses/by-nc/4.0) which permits unrestricted noncommercial use, distribution, and reproduction in any medium, provided the original work is properly cited.
[10]. The median age at diagnosis of GISTs is 60 years, and GISTs do not have any sex or race predominance [11]. Surgical resection remains the gold standard management for GISTs, and imatinib is currently used in the neoadjuvant, adjuvant, and metastatic disease setting [12].

Despite the rare occurrence of various colorectal nonadenocarcinomas, surgical resection is considered important for the cure. Further studies are needed to better understand the progression and long-term oncological outcomes of these rare tumors.

\section{CONFLICT OF INTEREST}

No potential conflict of interest relevant to this article was reported.

\section{REFERENCES}

1. Kang H, O'Connell JB, Leonardi MJ, Maggard MA, McGory ML, Ko CY. Rare tumors of the colon and rectum: a national review. Int J Colorectal Dis 2007;22:183-9.

2. Nam S, Kim D, Jung K, Choi YJ, Kang JG. Analysis of the incidence and clinical features of colorectal nonadenocarcinoma in Korea: a national cancer registry-based study. Ann Coloproctol 2020;36:390-7.

3. Ahmed M. Gastrointestinal neuroendocrine tumors in 2020 . World J Gastrointest Oncol 2020;12:791-807.

4. Caplin M, Sundin A, Nillson O, Baum RP, Klose KJ, Kelestimur F, et al. ENETS Consensus Guidelines for the management of patients with digestive neuroendocrine neoplasms: colorectal neuroendocrine neoplasms. Neuroendocrinology 2012;95:88-97.

5. Anthony LB, Strosberg JR, Klimstra DS, Maples WJ, O’Dorisio TM, Warner RR, et al. The NANETS consensus guidelines for the diagnosis and management of gastrointestinal neuroendocrine tumors (nets): well-differentiated nets of the distal colon and rectum. Pancreas 2010;39:767-74.

6. Basuroy R, Haji A, Ramage JK, Quaglia A, Srirajaskanthan R. Review article: the investigation and management of rectal neuroendocrine tumours. Aliment Pharmacol Ther 2016;44:332-45.

7. Yoon SN, Yu CS, Shin US, Kim CW, Lim SB, Kim JC. Clinicopathological characteristics of rectal carcinoids. Int J Colorectal Dis 2010;25:1087-92. 


\section{Coloproctology Jung Wook Huh}

8. DeMatteo RP, Lewis JJ, Leung D, Mudan SS, Woodruff JM, Brennan MF. Two hundred gastrointestinal stromal tumors: recurrence patterns and prognostic factors for survival. Ann Surg 2000; 231:51-8.

9. Nishida T, Hirota S. Biological and clinical review of stromal tumors in the gastrointestinal tract. Histol Histopathol 2000;15:1293301.

10. Scarpa M, Bertin M, Ruffolo C, Polese L, D’Amico DF, Angriman I.
A systematic review on the clinical diagnosis of gastrointestinal stromal tumors. J Surg Oncol 2008;98:384-92.

11. Raut CP, DeMatteo RP. Prognostic factors for primary GIST: prime time for personalized therapy? Ann Surg Oncol 2008;15:46.

12. Kelley KA, Byrne R, Lu KC. Gastrointestinal stromal tumors of the distal gastrointestinal tract. Clin Colon Rectal Surg 2018;31:295300 . 